IRA-International Journal of Applied Sciences ISSN 2455-4499; Vol.11, Issue 03 (June 2018)

Pg. no. 30-36.

Institute of Research Advances

https://research-advances.org/index.php/IRAJAS

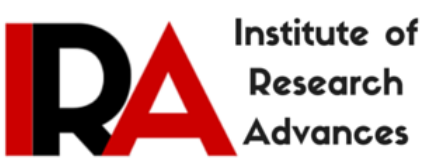

\title{
The Effect of Brine on Organisms-Hydrobionts
}

\author{
Issayeva A. U. ${ }^{1 \#}$, Bishimbayev V. K. ${ }^{1}$, Zhumagulyeva A. I. ${ }^{2}$ \\ ${ }^{1}$ Public Fund 'Scientific -Research Center of Salt Technologies', Astana city, Kazakhstan. \\ ${ }^{2}$ Shymkent University, Shymkent city, Kazakhstan.
}

\# corresponding author.

Type of Review: Peer Reviewed.

DOI: http://dx.doi.org/10.21013/jas.v11.n3.p1

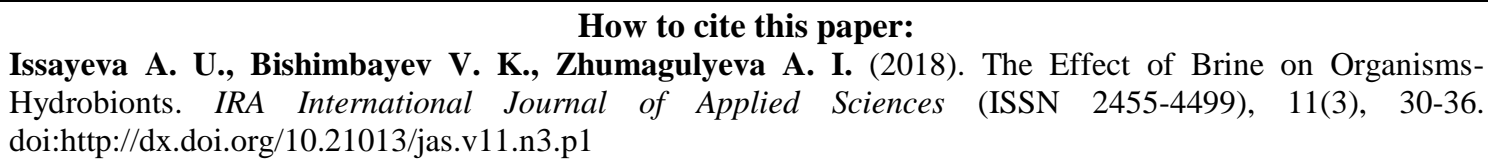

(C) Institute of Research Advances.

(cc) BY-No

This work is licensed under a Creative Commons Attribution-Non Commercial 4.0 International License subject to proper citation to the publication source of the work.

Disclaimer: The scholarly papers as reviewed and published by the Institute of Research Advances (IRA) are the views and opinions of their respective authors and are not the views or opinions of the IRA. The IRA disclaims of any harm or loss caused due to the published content to any party.

Institute of Research Advances is an institutional publisher member of Publishers International Linking Association Inc. (PILA-CrossRef), USA. The institute is an institutional signatory to the Budapest Open Access Initiative, Hungary advocating the open access of scientific and scholarly knowledge. The Institute is a registered content provider under Open Access Initiative Protocol for Metadata Harvesting (OAI-PMH).

The journal is indexed \& included in CAS Source Index of Chemical Abstracts Service of American Chemical Society (USA), Index Copernicus (IC Value 85.27), WorldCat Discovery Service (USA), CrossRef Metadata Search (USA), WorldCat (USA), OCLC (USA), Open J-Gate (India), EZB (Germany) Scilit (Switzerland), Airiti (China), Bielefeld Academic Search Engine (BASE) of Bielefeld University, Germany, PKP Index of Simon Fraser University, Canada. 


\begin{abstract}
The problem of salinization of water resources associated with the drying of the Aral sea is one of the urgent problems of Kazakhstan. Annual salt storms cover hundreds of kilometers around the sea with a salt layer. Salinization of water resources leads to changes in the population structure of aquatic organisms. On the other hand, the influence of brine on aquatic organisms is not well understood. As a result of the work it was found that the introduction of the surface brine of lake Zhaksy-Klych, located near the Aral sea, into the aquatic environment in a ratio of 1:1 causes the death of all protozoal organisms, and in the cells of filamentous algae there was a convex plasmolysis. The most resistant diatoms in which the introduction of brine into the water causes a gradual plasmolysis of convex and convulsive form.
\end{abstract}

Key words: Aral sea, lake Zhaksy-Klych, salinization, brine, hydrobiont organisms.

\title{
Introduction
}

Environmental problems associated with the changes in the Aral sea are important not only for Kazakhstan, but also for neighboring countries. Currently, the level of the Aral sea has decreased compared to 1957. (then the absolute mark was $54 \mathrm{~m}$ ) more than $14 \mathrm{~m}$. Its area decreased from 66.5 thousand $\mathrm{km}^{2}$ to about 36 thousand $\mathrm{km}^{2}$, the volume of water from $1000 \mathrm{~km}^{3}$ to $320 \mathrm{~km}^{3}$. The salinity of the water during this time increased from 8 to 14 $\mathrm{g} / \mathrm{l}$ to a value of $25-50 \mathrm{~g} / \mathrm{L}$. The area of the exposed bottom is approximately 3 million hectares In the Aral sea have become common salt dust storms. Annually, according to the laboratory of space monitoring, beyond the borders of the Aral sea with the wind blow in about 72 million tons of salt. The content of sulphates exceeds $31 \%$ (of the total amount of salts), and sodium chloride is only 54\%. The ionic composition of the following salts: sodium - from 2.83 to $13.73 \%$; sulfate - ion - 7,5 - 30,14; of calcium to 1.08; magnesium of 3.03; potassium - 0,93; carbonate -ion- 0,18; chlorine- 2,09; water- up to of 55.23\%. According to studies [1] 27$32 \%$ of the waters of the Aral sea belong to polyhaline,47-52\% hyperhaline and only $0.5-3.0 \%$ of present freshwater.

Salinity is mainly associated with high sodium content in the soil. Depending on the predominant accumulation of individual sodium salts salinity can be sulfate, chloride, soda or mixed. Na+ and CI-ions have the most harmful effect. The effect of salinization on plant organisms is due to two reasons: the deterioration of the water balance and the toxic effect of high concentrations of salts. Under the influence of salts there are violations of cell ultrastructure, in particular changes in the structure of chloroplasts. This is especially evident in salinity chloride. The harmful effect of high salt concentration is associated with damage to membrane structures, in particular plasma membrane, which increases its permeability, loses the ability to selective accumulation of substances. Water salinity is a determining factor in the adaptation of hydrobionts to the environment.

The basis of adaptation mechanisms is the regulation of ion concentration in intracellular fluid and its osmotic pressure [11]. The concentration of inorganic ions in the water environment can vary in a very wide range (from zero to values hundreds of times higher than their intracellular level in hydrobionts). This leads to the fact that the ion gradient between the body and the environment in which it is located, can be high. The greater the difference between osmotic concentration in the aquatic environment and in the body, the more severe the effects need to resist hydrobionts. The problem of adaptation is the regulation of not only quantitative but also qualitative differences in the ionic composition of the body cells and the environment.

Maintenance of cytoplasm osmotic pressure in different conditions salinity of the water environment is carried out by two mechanisms: concentrations in the cytoplasm of organic osmotically active substances (amino acids, urea, methylamines and other compounds synthesized in the body) and changes in the content of inorganic ions [14]. Optimal $\mathrm{NaCl}$ concentrations for freshwater crustaceans can range from 0 to $2 \%$ [8]. According to [7], $\mathrm{NaCl}$ in concentrations above or below optimal but still within acceptable limits may play the role of a stress factor capable of causing changes in physiology, morphology, behavior of organisms. The effect of the salinity of the ponds on the suitability[4] and change of the population structure of organisms-hydrobionts was studied $[3,5]$.

With increasing water salinity in invertebrates may increase enzymatic activity of glutamate dehydrogenase, an enzyme that catalyzes the synthesis of glutamine and other amino acids[15]. In mussels with increasing salinity to $35 \%$ content of nitrogen compounds in the cytoplasm of cells increases 5-6 times, and inorganic electrolytes1,1-1,2 times. A compensatory increase in intracellular pressure, occurring mainly due to organic substances considered as an important factor in the adaptation of hydrobionts to hypergaline medium [14]. Changes in the 
salinity of the aquatic environment have a significant impact on Daphnia magna: life expectancy [2], their growth rate [6], size [13], number of offspring [9, 10,12]. On the other hand, in the literature there is not enough information about the influence of brine on aquatic organisms.

In this regard, the aim of the study was to study the reaction of aquatic organisms to brine from lake ZhaksyKlych, located near the Aral sea.

\section{Objects and methods of research}

As objects of research were used: surface brine, brine from the halite layer, brine from the sulphate layer, selected from the well 180yu, coordinates (WGS 84): n.1. 46052'19,1", e.1. 61058 '32,23" Zhaksy-Klych lakes near the Aral sea.

Samples of brine were taken to sterile glass containers from 5 different places from a depth of 0-0.3 m.

Microscopes "Tauda" and "Mikmed-5", methods of light microscopy, were used in microscopic studies.

To study the influence of brine on the life of organisms-hydrobionts, a brine drop (0.2 ml) was introduced on a slide with a drop $(0.2 \mathrm{ml})$ of the culture storage under continuous microscopy.

Statistical processing of the results was carried out by calculating the arithmetic mean value and the standard deviation. All definitions were carried out in 3 and 5-fold repetition. The data was processed using IBM's "Pentium" personal computer on the basis of "Excel" application software packages.

\section{Results of the study and their discussion}

Microscopy of surface brine samples from lake Zhaksy-Klych showed the absence of living objects. Crystals of different sizes of cuboidal shape were found (Figure 1).

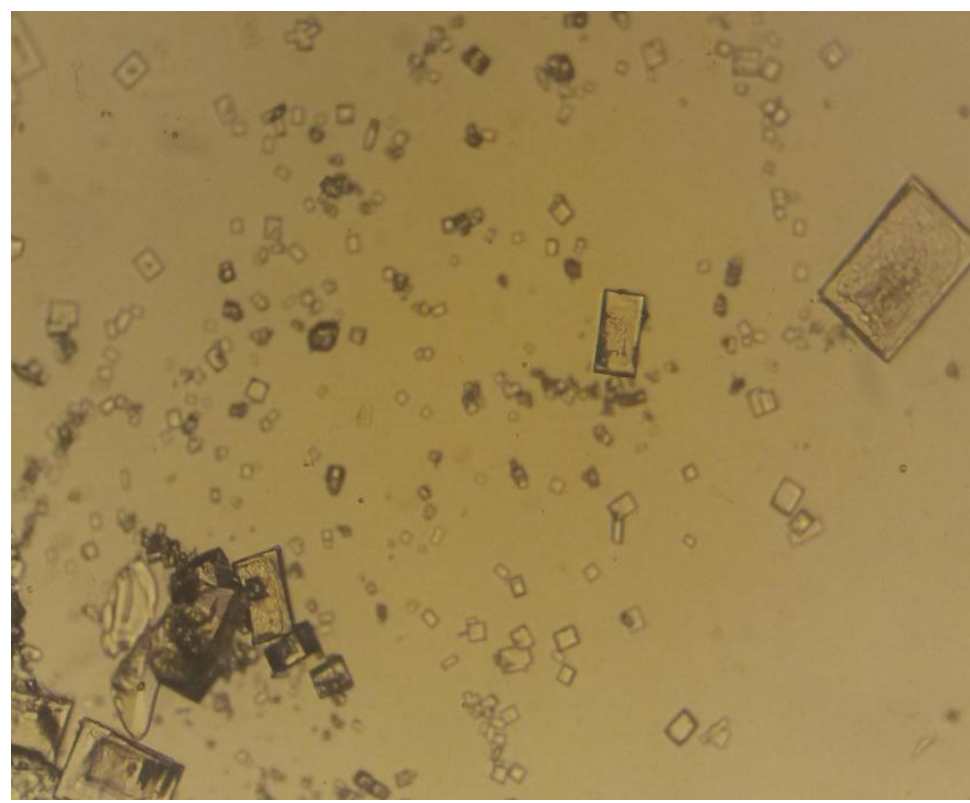

Figure 1. Types of salt crystallization in surface brine $(\times 100)$

In brine, selected from galite bed of the reservoir from depth $0.3 \mathrm{~m}$ apart from the cuboidal shapes of salt crystals revealed amorphous formation and a few amoeboid structure (Figure 2). Bacterial microflora represented by small cocci and diplococci was noted. 


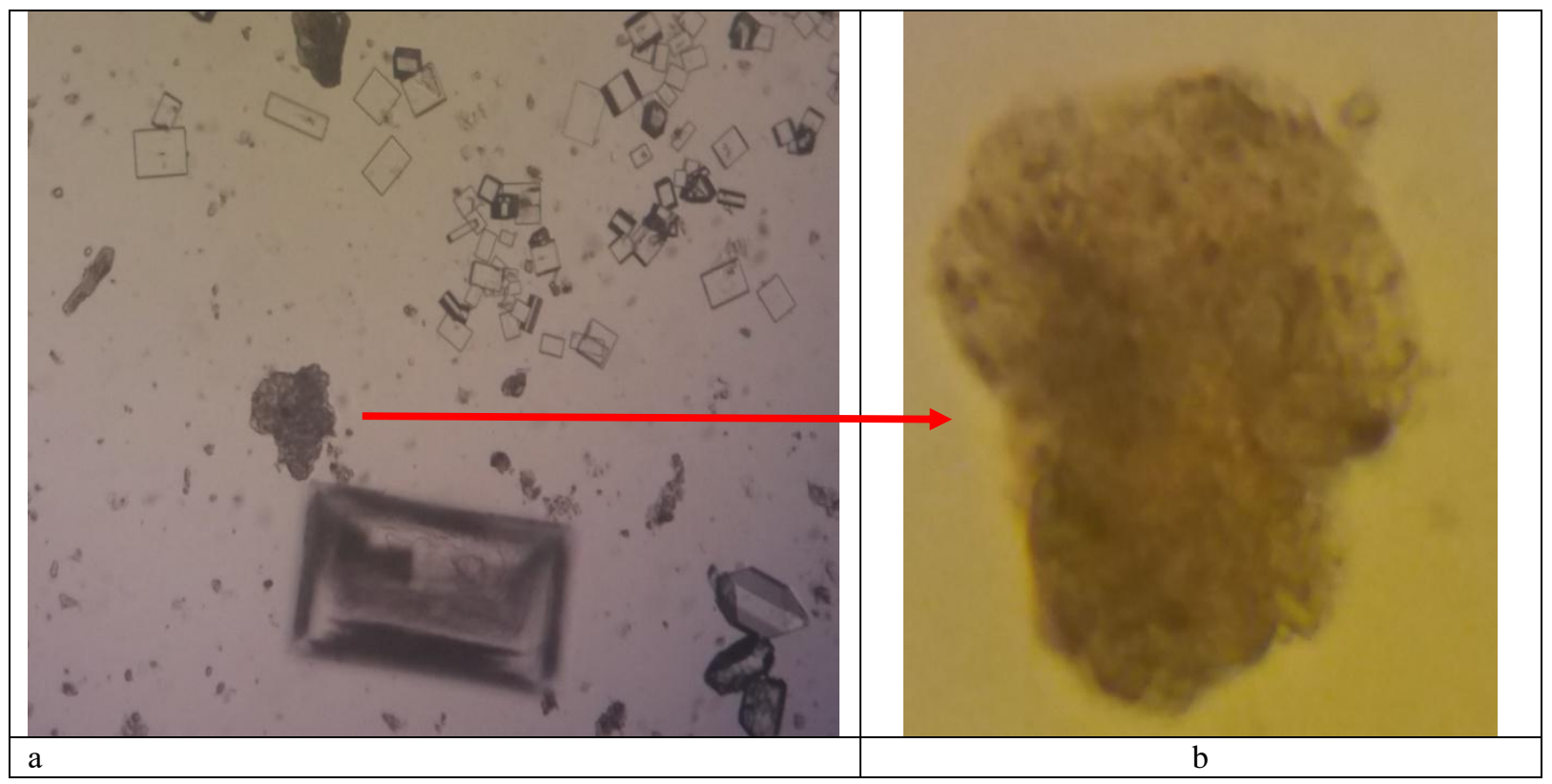

a. General view $(\times 100)$; b. amorphous education $(\times 400)$

Figure 2. Microscopic the brine from reservoir Gallinago

In the above-seeding fluid of the brine, selected from the sulfate layer, from a depth of $0.5 \mathrm{~m}$, single amoeboid structures were revealed, the number of which is abundant in the sediment (Figure 3).In contrast to the correct geometric shapes of salt crystals, in the sample of discovered rare sticks with rounded ends. Microflora is represented by small coccoid and rod-shaped mobile bacteria.

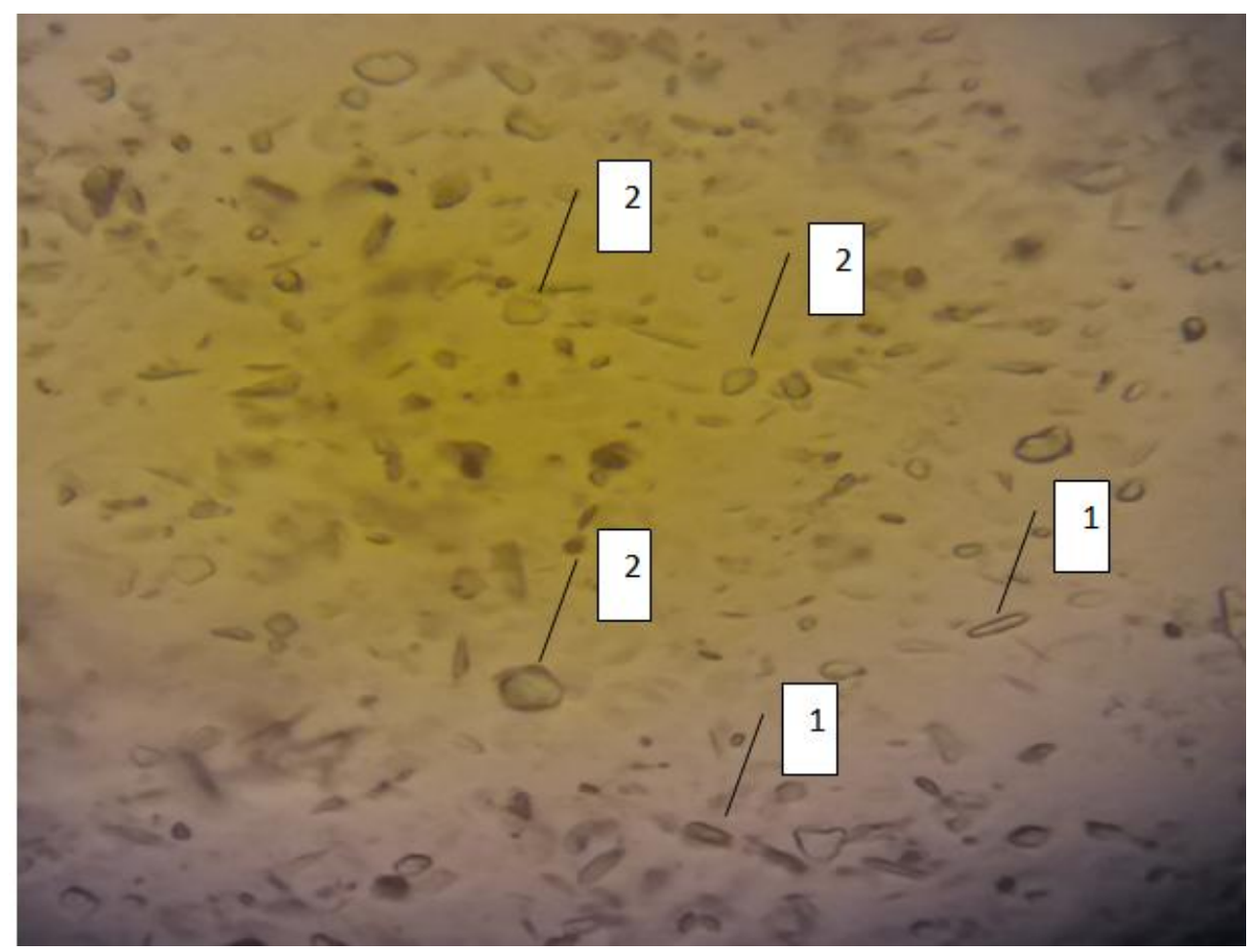

1.Sticks with rounded ends. 2. Amoeboid formations

Figure 3. Microscopic view of sulphate formation brine $(\times 400)$

In studying the effect of three types of brine on organisms-hydrobionts have been used cumulative culture, which contains 16 species of organisms-aquatic organisms: including 10 species of protozoa: Chilodonella uncinata, Colpidium campylum, Oxitricha fallax, Euplotes patella, Stylonichia mytilis, Euglena viridis, Colpoda 
intlata, Pelomixa palustris, Amoeba limax, Vorticella macrostoma and 6 species of algal flora: Cladophora glomerata, Amphora ovalis, Navicula diluviana,N. elegans, Diatoma vulgare, Meridion circulare (Figure 4).

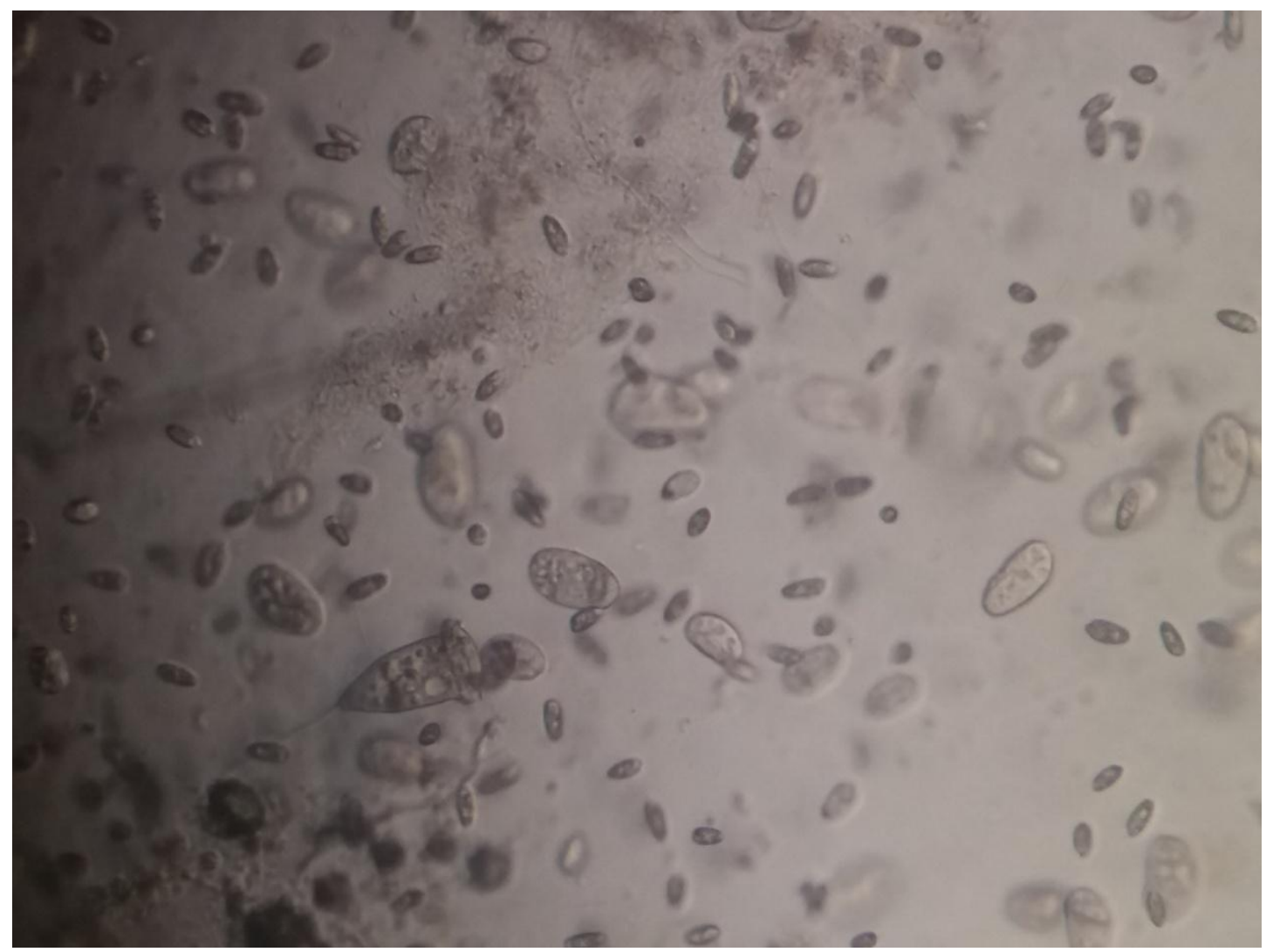

Figure 4. Cumulative culture of organisms-hydrobionts

The introduction of all types of brine into the water with the culture storage in a ratio of 1:1 leads within 1-2 minutes to slow down the movement of the simplest. Further, it is possible to note the formation of vacuoles around the perimeter of the cells, ending in the rupture of the cells (Figure 5).

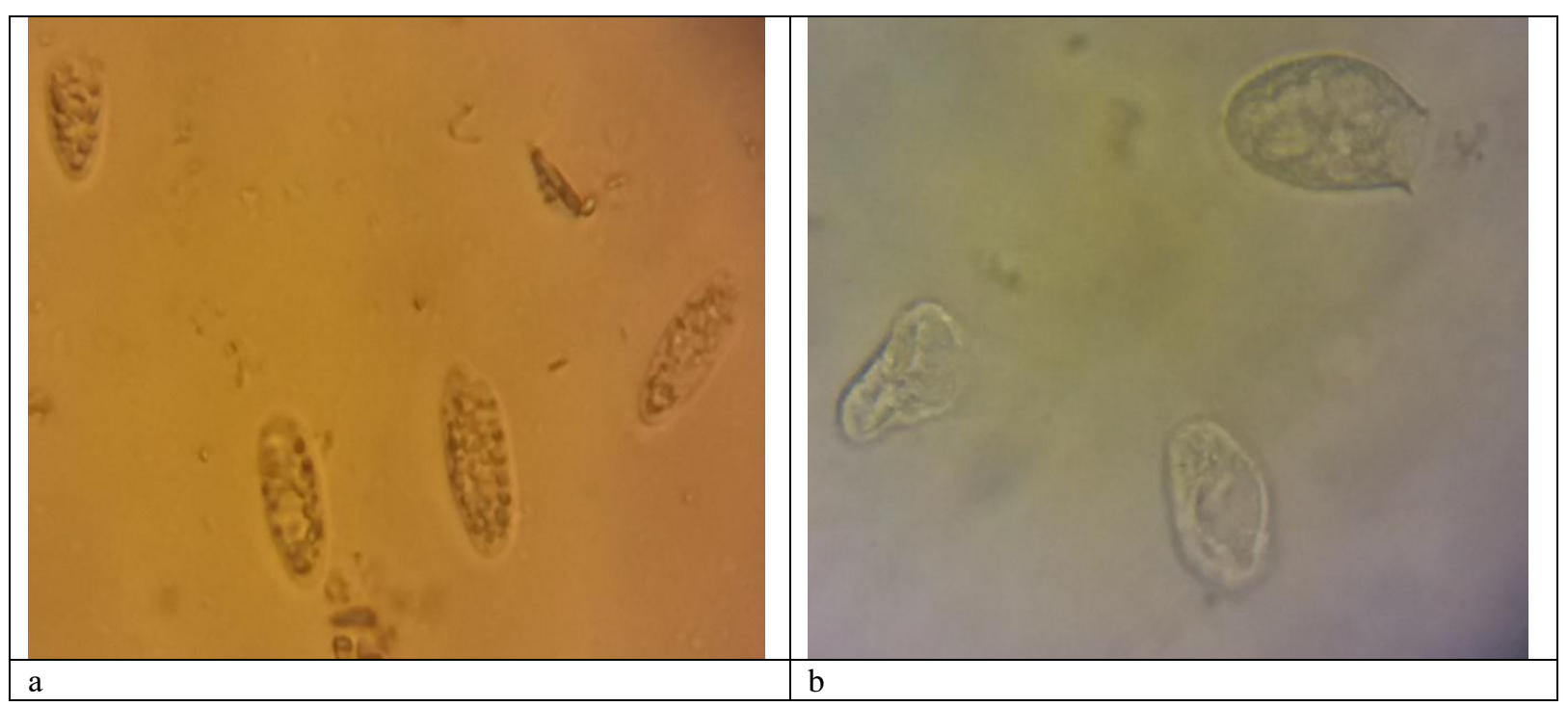

a. After 2-3 minutes; b. After 5-7 minutes

Figure 5. The reaction of ciliates to the introduction of brine into the water 
Reaction of filamentous algae Cladophora glomerata to introduction of brine into water is manifested in the form of convulsive plasmolysis (Figure 6).

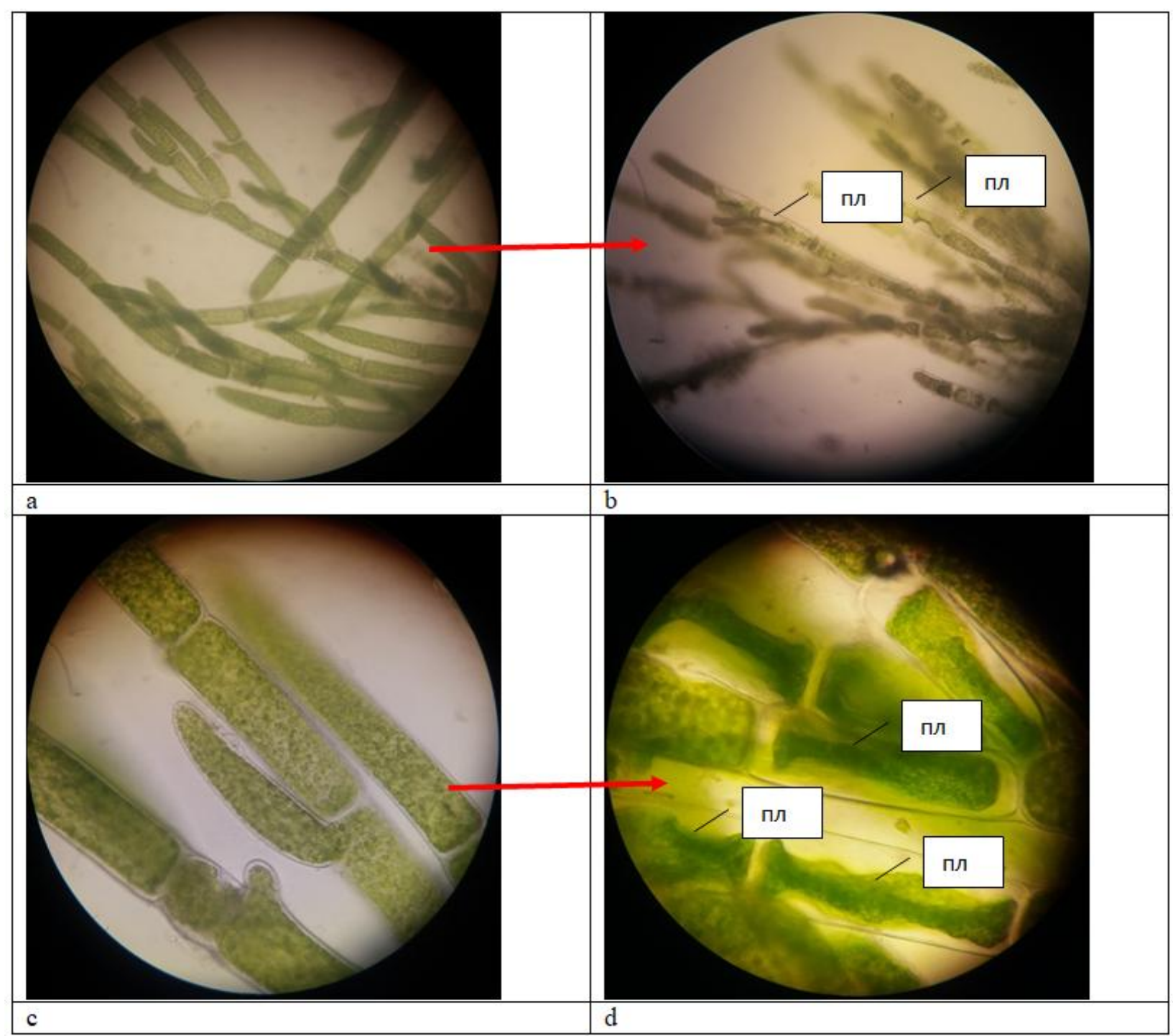

a.The filaments of $\mathrm{C}$. glomerata in a state of tension to the experience (X100), b. after the introduction of brine $(\mathrm{X100}), \mathrm{c}$. the algae cells in a state of tension to the experience $(\mathrm{X} 400), \mathrm{d}$. after the introduction of brine (X400): PL-convulsive plasmolysis

Figure 6. The reaction of Cladophora glomerata to the introduction of brine into water

Diatoms were more resistant to the introduction of brine into the water. Changes in the structure of the cytoplasm of diatoms in the form of convex plasmolysis are observed after 60-70 minutes from the introduction of brine (Figure 7).

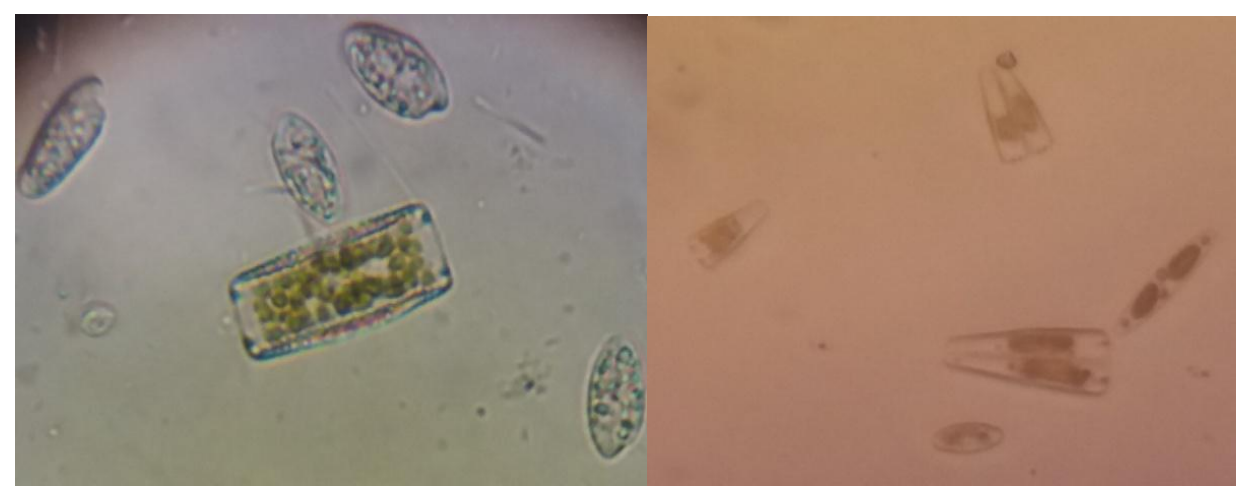

Figure 7. Type of diatoms 20 minutes after the introduction of brine into the water 


\section{Conclusion}

Thus, as a result of the work it was found that the introduction of surface brine into the aqueous medium in a ratio of 1:1 causes the death of all protozoal organisms, in the cells of filamentous algae there was a convex plasmolysis. The most resistant diatoms, in which the introduction of brine into the water causes plasmolysis convex and convulsive form.

Research Findings and Research Nomenclature
The work was carried out within the framework of the grant of the Ministry of education and science of the Republic
of Kazakhstan AR05131728: "Development of production technology and obtaining prototypes of new cosmetic
products on the basis of pharmacological studies of domestic salt and plant raw materials"(2018-2020).

\section{References}

[1]. Aladin J. N., Micklin P. and Plotnikov I. (2008). Biodiversity of the Aral Sea and its importance to the possible ways of rehabilitating and conserving its remnant water bodies. In: NATO Science for Peace and Security Series - C: Environmental Security. Environmental Problems of Central Asia and their Economic, Social and Security Impacts. Edited by Jiaguo Qi, Kyle T. Evered. Springer, pp. 73-98.

[2]. Casey R., Scrimgeour G. and Kendall S. (2000). Final report: Effects of water temperature and treated pulp mill effluent on survival and growth of Daphnia magna (Cladocera: Daphnidae) and Taenionema (Plecoptera Taeniopterygidae). Alberta Environment Sustainable Forest Management Research Program. - T / 678.

[3]. Derevenskaya O. and Urazaeva N. (2018). Evaluation of the lake Lyabiazhie (Kazan, Russia) state by indicators of communities of hydrobionts IOP Conf. Ser.: Earth Environ. Sci. 107012129

[4]. Ejsmont-Karabin J and Karabin A.(2013). The suitability of zooplankton as lake ecosystem indicators: crustacean trophy state index Polish Journal of Ecology 61 (3) pp 561-573

[5]. Haberman J. and Haldna M. (2014). Indices of zooplankton community as valuable tools in assessing the trophy state and water quality of eutrophic lakes: long term study of Lake Võrtsjärv J. Limnol. 73 (2) pp 263-273 ORIGINAL ARTICLEDOI: $10.4081 /$ jlimnol.2014.828

[6]. Hall C. J. and Burns C. W. (2002). Mortality and growth response of Daphnia carinata to increases in temperature and salinity. Freshwat. -Biol. 47. - P. 451-458.

[7]. Horrigan N. (2005). Response of stream macroinvertebrates to changes in salinity and the development of a salinity index. Mar. Freshwat. Res. -56. - P 825-833.

[8]. Jeppesen M. (1994).Does the impact of nutrients on the biological structure and function of brackish and freshwater lakes differ? Hydrobiology. - 275/276. - P. 15-30.

[9]. Martnez-Jernimo F. and Espinosa-Chvez F. (2005). Notes on the reproduction and survival of Moina 193. hutchinsoni Brehm, 1937 (Moinidae: Anomala) grown in media of varying salinity. Aquat. Ecol. - 39. - P. 113-118.

[10]. Martnez-Jernimo F., Martnez-Jernimo L. and Espinosa-Chvez F. (2005).Demographic study of salinity tolerance of a 194. freshwater strain of Daphnia magna (Cladocera). VII International Symposium on Cladocera, Herzberg, - P. 29.

[11]. Ryzhkov L. P., Artemieva N. B. and Kamenskaya T. V. (2009). Some aspects of adaptation of freshwater crustaceans Daphnia magna to salinity. Proceedings of the XXVIII International conference: Biological resources of the white sea and inland waters of the European North. - Petrozavodsk: Karelian research centre of RAS,-S. 478-480(on Russian).

[12]. Sarma, S. (2005).Effect of salinity stress on the life history variables of Branchipus schaefferi Fisher 1834 (Crustacea: Anostraca). Saline Systems. - 1. - R. 4.

[13]. Teschner, M. (1995). Effects of salinity on the life history and fitness of Daphnia magna variability within and between populations. Hydrobiology. - 307. - P. 33-41.

[14]. Wang Y., Mopper S. and Hasenstein K. H. (2001). Effects of salinity on endogenous levels of ABA, IAA, JA, and SA in Iris hexagona. Journal of Chemical Ecology. - 27. - P. 327 - 342.

[15]. Weider L. J. and Hebert P. D. N. (1987). Microgeographic enetic heterogeneity of melanic Daphnia pulex at a lowarctic site. Heritage.- - 58. - P. 391-399. 